\title{
Structures of inactive retinoblastoma protein reveal multiple mechanisms for cell cycle control
}

\author{
Jason R. Burke, ${ }^{1}$ Greg L. Hura, ${ }^{2}$ and Seth M. Rubin ${ }^{1,3}$ \\ ${ }^{1}$ Department of Chemistry and Biochemistry, University of California at Santa Cruz, Santa Cruz, California 95064, USA; \\ ${ }^{2}$ Physical Biosciences Division, Lawrence Berkeley National Laboratory, Berkeley, California 94720, USA
}

Cyclin-dependent kinase (Cdk) phosphorylation of the Retinoblastoma protein ( $R b)$ drives cell proliferation through inhibition of $\mathbf{R b}$ complexes with E2F transcription factors and other regulatory proteins. We present the first structures of phosphorylated $\mathrm{Rb}$ that reveal the mechanism of its inactivation. $S 608$ phosphorylation orders a flexible "pocket" domain loop such that it mimics and directly blocks E2F transactivation domain $\left(\mathrm{E} 2 \mathrm{~F}^{\mathrm{TD}}\right)$ binding. T373 phosphorylation induces a global conformational change that associates the pocket and N-terminal domains $(\mathbf{R b N})$. This first multidomain $\mathbf{R b}$ structure demonstrates a novel role for $\mathbf{R b N}$ in allosterically inhibiting the $\mathrm{E}^{\mathrm{F}} \mathrm{TD}^{\mathrm{TD}}$-pocket association and protein binding to the pocket "LxCxE" site. Together, these structures detail the regulatory mechanism for a canonical growth-repressive complex and provide a novel example of how multisite Cdk phosphorylation induces diverse structural changes to influence cell cycle signaling.

[Keywords: Retinoblastoma protein; cell cycle regulation; multisite phosphorylation; cyclin-dependent kinase; X-ray crystal structure; small-angle X-ray scattering (SAXS)]

Supplemental material is available for this article.

Received February 15, 2012; revised version accepted April 13, 2012.

Cyclin-dependent kinases (Cdks) control key events in the cell cycle through protein phosphorylation. Multisite phosphorylation of Cdk substrates induces complex signaling properties such as sensitivity and switch-like behavior and permits diverse outputs (Nash et al. 2001; Mimura et al. 2004; Kim and Ferrell 2007; Holt et al. 2009; Koivomagi et al. 2011). The structural effects of Cdk substrate phosphorylation are less well characterized, as studied examples have been limited to proteins in which phosphorylation creates a linear binding epitope for direct association with degradation factors (Orlicky et al. 2003; Hao et al. 2005). Thus, the structural mechanisms by which phosphorylation of a single substrate can generate multiple distinct signaling outputs are largely unknown.

Retinoblastoma protein $(\mathrm{Rb})$ is inactivated by multisite Cdk phosphorylation in normal and cancerous cell cycles (Buchkovich et al. 1989; DeCaprio et al. 1989; Lees et al. 1991; Hinds et al. 1992; Weinberg 1995; Burkhart and Sage 2008). Rb regulates transcription to affect a number of processes related to cell growth and differentiation. Its best-characterized activity is control of the G1-S transition in the cell cycle. Rb binds and inhibits E2F transcrip-

\footnotetext{
${ }^{3}$ Corresponding author.

E-mail srubin@ucsc.edu.

Article published online ahead of print. Article and publication date are online at http://www.genesdev.org/cgi/doi/10.1101/gad.189837.112.
}

tion factors, thereby preventing activation of E2F genes that stimulate S-phase progression. In addition to its association with E2F, $\mathrm{Rb}$ is found in complexes with a number of other proteins, such as regulators of chromatin and chromosome structure and ubiquitin ligases (Brehm et al. 1998; Nielsen et al. 2001; Ji et al. 2004; Binne et al. 2007; van den Heuvel and Dyson 2008; Manning and Dyson 2011). The association of $\mathrm{Rb}$ with E2F and many of these other complexes is regulated by Cdk phosphorylation (Buchkovich et al. 1989; DeCaprio et al. 1989; Lees et al. 1991; Hinds et al. 1992; Knudsen and Wang 1997; Zarkowska and Mittnacht 1997; Brown et al. 1999; Harbour et al. 1999; Rubin et al. 2005; Lents et al. 2006; Gorges et al. 2008; Burke et al. 2010); however, it is unknown how $\mathrm{Rb}$ phosphorylation changes its structure to inhibit these interactions.

$\mathrm{Rb}$ contains the $\mathrm{N}$-terminal $(\mathrm{RbN})$ and pocket domains and several intrinsically disordered regions: the interdomain linker between the two independently folded domains (RbIDL), the large loop within the pocket domain $(\mathrm{RbPL})$, and the C-terminal domain (RbC) (Fig. 1A). Structures of isolated domains have been determined; however, interdomain interactions and their relevance for $\mathrm{Rb}$ function are less well characterized (Lee et al. 1998; Rubin et al. 2005; Hassler et al. 2007). The Rb-E2F complex is stabilized primarily by an association between the E2F transactivation domain $\left(\mathrm{E}_{2} \mathrm{~F}^{\mathrm{TD}}\right)$ and the $\mathrm{Rb}$ pocket domain 
A

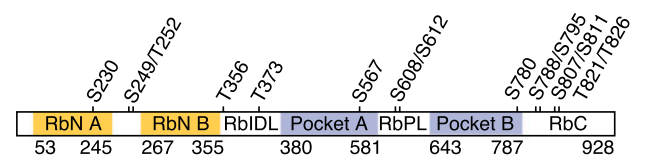

B

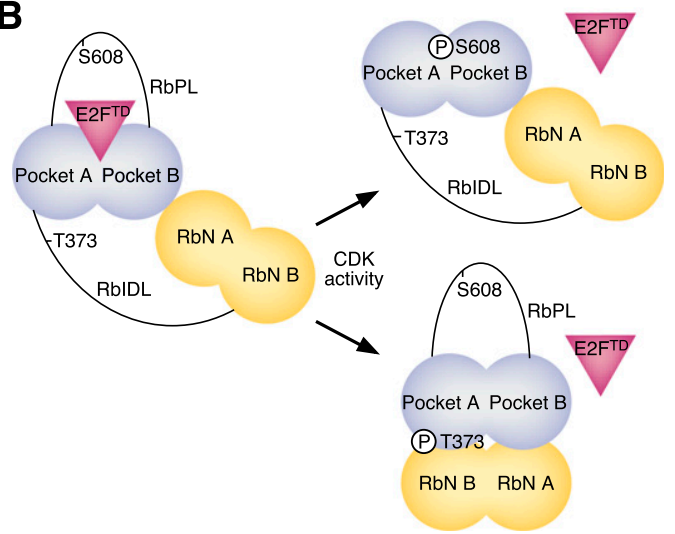

Figure 1. Overall $\mathrm{Rb}$ structure and phosphorylation-induced conformational changes. $(A)$ Domain architecture of $\mathrm{Rb}$. The two structured domains, $\mathrm{RbN}$ and the pocket, are colored gold and blue, respectively. Disordered sequences, including RbIDL, $\mathrm{RbPL}$, and $\mathrm{RbC}$, are uncolored. Conserved Cdk consensus sites are indicated. $(B)$ Phosphorylation-induced conformational changes presented here that result in $\mathrm{Rb}-\mathrm{E} 2 \mathrm{~F}^{\mathrm{TD}}$ complex inhibition. Phosphorylation of S608 causes RbPL to bind to the pocket domain in a manner that competitively inhibits $E 2 \mathrm{~F}^{\mathrm{TD}}$ binding. Phosphorylation of T373 induces an interdomain association that allosterically inhibits $\mathrm{E}^{\mathrm{T}} \mathrm{F}^{\mathrm{TD}}$ binding.

(Lee et al. 2002; Xiao et al. 2003). Tumorigenic viral proteins such as the human papillomavirus E7 protein use an "LxCxE" motif to associate with the pocket domain at a site distinct from E2F ${ }^{\mathrm{TD}}$ binding (Lee et al. 1998). Other cellular proteins bind the $\mathrm{LxCxE}$ cleft or other sites in the pocket domain, but the precise determinants for these associations have not been found (Brehm et al. 1998; Nielsen et al. 2001; Ji et al. 2004; van den Heuvel and Dyson 2008; Manning and Dyson 2011).

Cdk phosphorylation beginning in G1 occurs at 13 consensus sites in unstructured regions of $\mathrm{Rb}$, including RbIDL, RbPL, and RbC (Lees et al. 1991; Zarkowska and Mittnacht 1997). Several studies have indicated that distinct phosphorylation events modulate specific $\mathrm{Rb}$ associations with E2F and other proteins. For example, T821/ T826 phosphorylation inhibits histone deacetylase and viral protein binding to the pocket domain (Knudsen and Wang 1996; Harbour et al. 1999; Rubin et al. 2005). The specific association between $\mathrm{E} 2 \mathrm{~F}^{\mathrm{TD}}$ and the pocket domain is inhibited by both T356/T373 phosphorylation in RbIDL and S608 phosphorylation in RbPL (Knudsen and Wang 1997; Burke et al. 2010). Here we characterize the structural effects of these phosphorylation events using X-ray crystallography and small-angle X-ray scattering (SAXS). We found that T373 and S608 phosphorylation each produce unique structural changes that result in allosteric and direct E2F ${ }^{\mathrm{TD}}$ inhibition (Fig. 1B). Our study reveals a novel role for $\mathrm{RbN}$ in the mechanism of $\mathrm{Rb}$ inactivation and provides the first insights into the overall structure of the multidomain $\mathrm{Rb}$ protein. The distinct structural changes induced by particular phosphorylation events explain how multisite phosphorylation can differentially regulate $\mathrm{Rb}$ interactions with other proteins.

\section{Results}

Phosphorylated RbPL binds the pocket domain at the $E 2 F^{T D}$ site

We first aimed to elucidate the mechanism of E2F inhibition by S608 phosphorylation in RbPL (Fig. 1B). S608 phosphorylation inhibits $\mathrm{E}^{\mathrm{F}} \mathrm{F}^{\mathrm{TD}}$ binding even in the context of the isolated pocket domain (Knudsen and Wang 1997; Burke et al. 2010). To observe the structural effect of phosphorylation, we solved the $2.0 \AA$ crystal structure of a pocket domain construct with a phosphoserine-mimetic S608E and a shortened RbPL (Table 1; Fig. 2). The crystallized protein $\left(\mathrm{Rb}^{380-787 \Delta 616-642 / \mathrm{S} 608 \mathrm{E} / \mathrm{S} 612 \mathrm{~A} / \mathrm{S} 780 \mathrm{~A}}\right.$; hereafter called $\mathrm{Rb}^{\mathrm{PL}-\mathrm{P}}$ ) binds $\mathrm{E} 2 \mathrm{~F}^{\mathrm{TD}}$ with a reduced affinity that indicates that the glutamate mutation functionally mimics S608 phosphorylation (Supplemental Fig. 1). The structure was solved by molecular replacement using the

Table 1. Statistics from $X$-ray crystallography analysis

\begin{tabular}{|c|c|c|}
\hline & $\mathrm{Rb}^{\mathrm{PL}-\mathrm{P}}$ & $\mathrm{Rb}^{\mathrm{N}-\mathrm{P}}$ \\
\hline \multicolumn{3}{|l|}{ Data collection } \\
\hline Space group & H3 & $\mathrm{P} 2{ }_{1} 2_{1} 2_{1}$ \\
\hline \multicolumn{3}{|l|}{ Cell dimensions } \\
\hline$a, b, c$ & $\begin{array}{l}249.66 \AA, 249.66 \AA \text {, } \\
\quad 35.11 \AA\end{array}$ & $\begin{array}{c}51.62 \AA, 129.51 \AA, \\
135.04 \AA\end{array}$ \\
\hline$\alpha, \beta, \gamma$ & $90^{\circ}, 90^{\circ}, 120^{\circ}$ & $90^{\circ}, 90^{\circ}, 90^{\circ}$ \\
\hline Resolution & 36-2.0 А & 58-2.7 A \\
\hline $\mathrm{R}_{\text {pim }}{ }^{\mathrm{a}}$ & $4.2(33.1)$ & $5.9(31.0)$ \\
\hline $\mathrm{I} / \sigma^{\mathrm{I}}$ & $14.4(2.7)$ & $8.2(2.3)$ \\
\hline Completeness & $99.9 \%(100.0 \%)$ & $92.3 \%(90.0 \%)$ \\
\hline Redundancy & $6.0(5.9)$ & $4.9(5.0)$ \\
\hline \multicolumn{3}{|l|}{ Refinement } \\
\hline Resolution & $36-2.0 \AA$ & $58-2.7 \AA$ \\
\hline $\begin{array}{l}\text { Number of } \\
\text { reflections }\end{array}$ & 57,103 & 23,354 \\
\hline $\mathrm{R}_{\text {work }} / \mathrm{R}_{\text {free }}$ & $19.3 / 23.8$ & $21.2 / 26.6$ \\
\hline \multicolumn{3}{|l|}{ Number of atoms } \\
\hline Protein & 5606 & 4851 \\
\hline Water & 355 & 57 \\
\hline \multicolumn{3}{|l|}{ RMS deviations } \\
\hline Bond lengths & $0.008 \AA$ & $0.004 \AA$ \\
\hline Bond angles & $1.0^{\circ}$ & $0.9^{\circ}$ \\
\hline Average B factor & $39.5 \AA^{2}$ & $62.1 \AA^{2}$ \\
\hline \multicolumn{3}{|l|}{$\begin{array}{c}\text { Ramachandran } \\
\text { analysis }\end{array}$} \\
\hline Preferred & $97.7 \%$ & $95.0 \%$ \\
\hline Allowed & $2.3 \%$ & $4.7 \%$ \\
\hline Outliers & $0.0 \%$ & $0.3 \%$ \\
\hline
\end{tabular}

Values in parentheses correspond to the highest-resolution shell of data $\left(1.98-2.03 \AA\right.$ for $\mathrm{Rb}^{\mathrm{PL}-\mathrm{P}}$ and 2.70-2.77 $\AA$ for $\left.\mathrm{Rb}^{\mathrm{N}-\mathrm{P}}\right)$.

${ }^{\mathrm{a}} \mathrm{R}_{\text {pim }}=\sum_{\text {hkl }}\{1 /(N-1)\}^{1 / 2} \sum_{i}\left|\mathrm{I}_{i}(\mathrm{hkl})-\mathrm{I}(\mathrm{hkl})\right| / \sum_{\text {hkl }} \sum_{i} \mathrm{I}_{i}(\mathrm{hkl})$, where $i$ indexes the ith measurement of reflection hkl, and $N$ indicates the total number of times a given reflection is measured. 
Burke et al.

A

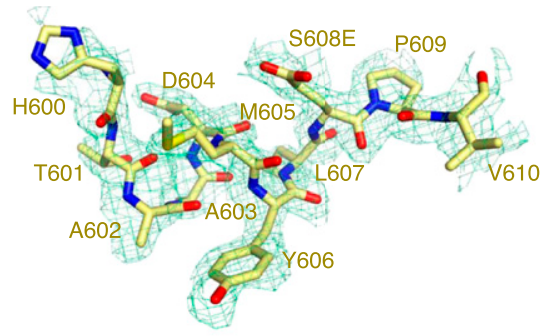

B

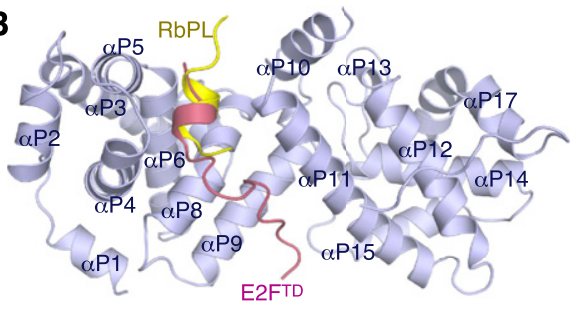

C

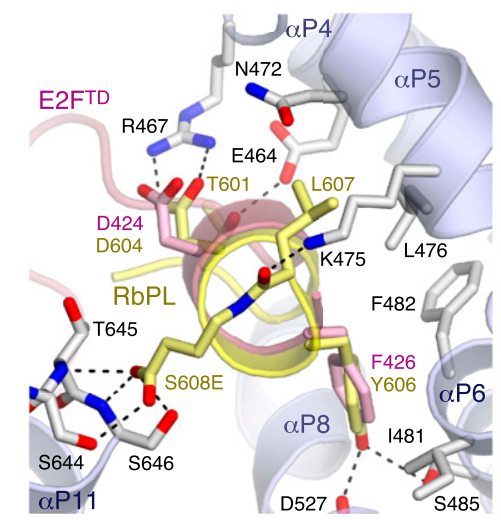

Figure 2. Structure of the $\mathrm{Rb}$ pocket domain bound by RbPL $\left(\mathrm{Rb}^{\mathrm{PL}-\mathrm{P}}\right)$. (A) Electron density is shown for the bound RbPL fragment. The mesh corresponds to a $1.5 \sigma \mathrm{f}_{\mathrm{o}}-\mathrm{f}_{\mathrm{c}}$ map that was generated from the molecular replacement solution and before the peptide was built into the model. (B) RbPL (yellow) binds at the interface between the A and B subdomains of the pocket (blue) and partially occludes the $\mathrm{E}_{2} \mathrm{~F}^{\mathrm{TD}}$-binding site (pink; rendered from PDB: $1 \mathrm{~N} 4 \mathrm{M})$. (C) Detailed interactions stabilizing the RbPLpocket interface and comparison with the $\mathrm{E}_{2} \mathrm{~F}^{\mathrm{TD}}$-pocket interface.

unliganded pocket domain as a search model (Balog et al. 2011), and density corresponding to RbPL was readily observable (Fig. 2A). Residues 600-610 of RbPL are ordered and bound to the pocket at the $\mathrm{E} 2 \mathrm{~F}^{\mathrm{TD}}$ site (Fig. $2 \mathrm{~B}$ ), which resides in a cleft between the $\mathrm{A}$ and $\mathrm{B}$ subdomains (Lee et al. 2002; Xiao et al. 2003). RbPL residues 602-607 form a short $\alpha$ helix similar to the helix found in the C-terminal half of $\mathrm{E}_{2} \mathrm{~F}^{\mathrm{TD}}$. Two of these RbPL residues structurally align with $\mathrm{E} 2 \mathrm{~F}^{\mathrm{TD}}$ side chains and contact the pocket in the same manner (Fig. 2C): D604 (D424 in E2F2 ${ }^{\mathrm{TD}}$ ) forms a salt bridge with R467, and $\mathrm{Y} 606$ (F426 in E2F2 ${ }^{\mathrm{TD}}$ ) makes van der Waals contacts with I481 and F482. E2F residues D424 and F426 are strictly conserved, and each forms interactions that are critical for tight binding with the $\mathrm{Rb}$ pocket (Lee et al. 2002; Xiao et al. 2003); thus, it is significant that $\mathrm{RbPL}$ makes analogous side chain interactions to act as an inhibitor.
Additional important RbPL contacts are not superimposable with E2F ${ }^{\mathrm{TD}}$ (Figs. 2C, 3). T601 in RbPL makes a side chain hydrogen bond with E464 from the pocket. The L607 side chain is buried within a hydrophobic pocket composed of side chains from residues N472 and L476 and the aliphatic portion of K475. The phosphoserinemimetic S608E binds the $\mathrm{N}$ terminus of helix $\alpha \mathrm{P} 11$, stabilizing the positive helix dipole and acting as a hydrogen bond acceptor for the amide protons of residues S644 and T645 and the hydroxyl side chains of S644 and S646. Interestingly, a similar interaction at the $\mathrm{N}$ terminus of $\alpha \mathrm{P} 11$ is made by an aspartate in the adenovirus E1A protein, which binds and dissociates Rb-E2F complexes for cellular transformation (Liu and Marmorstein 2007). When phosphorylated, S608 could form the hydrogen bond contacts observed for the glutamate mutant and also interact with the positive helix dipole (Supplemental Fig. 1). The critical role of D604, Y606, L607, and phosS608/S608E at the RbPL-pocket domain interface is consistent with previous observations of their importance in $\mathrm{E} 2 \mathrm{~F}^{\mathrm{TD}}$ inhibition (Burke et al. 2010). In sum, the $\mathrm{Rb}^{\mathrm{PL}-\mathrm{P}}$ structure demonstrates that $\mathrm{S} 608$ phosphorylation results in a bound and inhibitory conformation of RbPL that directly blocks the $\mathrm{E} 2 \mathrm{~F}^{\mathrm{TD}}$-binding site.

\section{Structure of the phosphorylated RbN-pocket complex}

We next set out to determine the mechanism of $\mathrm{Rb}$ inactivation by T356/T373 phosphorylation (Fig. 1B). The inhibitory effect of these sites in RbIDL on E2F ${ }^{\mathrm{TD}}$ binding requires the presence of $\mathrm{RbN}$ (Knudsen and Wang 1997; Burke et al. 2010). We therefore hypothesized that RbN and phosphorylated T356/T373 act on the pocket to form an inhibited structure. We generated an $\mathrm{Rb}$ construct suitable for structural studies that contains RbN, RbIDL, and the pocket, but lacks RbPL and an analogous disordered loop in $\mathrm{RbN}\left(\mathrm{Rb}^{53-787, \Delta 245-267, \Delta 582-642}\right.$; called $\left.\mathrm{Rb}^{\text {LLoops }}\right)$. Isothermal titration calorimetry experiments demonstrate that phosphorylation of $\mathrm{Rb}^{\text {LLoops }}$ modulates E2 $\mathrm{F}^{\mathrm{TD}}$ binding, as previously observed for the T356/T373 sites (Supplemental Fig. 2). We successfully determined the structure of phosphorylated $\mathrm{Rb}^{\Delta \text { Loops }}$ (hereafter called $\mathrm{Rb}^{\mathrm{N}-\mathrm{P}}$ ) containing two mutations (K289A and Y292A) that allow crystal packing and an S780A mutation that facilitates homogeneous phosphorylation (Table 1). These mutations do not affect $\mathrm{E} 2 \mathrm{~F}^{\mathrm{TD}}$ binding or the overall conformation in solution (Supplemental Figs. 2, 3).

The $2.7 \AA$ crystal structure of $\mathrm{Rb}^{\mathrm{N}-\mathrm{P}}$ reveals a closed conformation with $\mathrm{RbN}$ and the pocket associated across an extensive interface (Fig. 4A). The overall structures of the individual domains are similar to their structures observed in isolation (Lee et al. 1998; Hassler et al. 2007); both contain two subdomains composed primarily of helical cyclin folds. The $\mathrm{RbN}$-pocket association is composed of two sets of contacts, each involving residues from a unique pair of subdomains.

The larger interface $\left(2277 \AA^{2}\right.$ buried surface area) is formed between pocket subdomain $\mathrm{A}$ and $\mathrm{RbN}$ subdomain $\mathrm{B}$ and is mediated by T373 phosphorylation (Fig. 4B). The phosphothreonine side chain forms an interdomain salt 


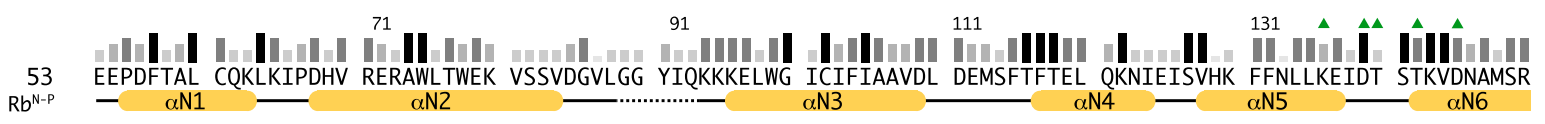

$\underset{\text { LLKKYDVLFA }}{\text { I }}$

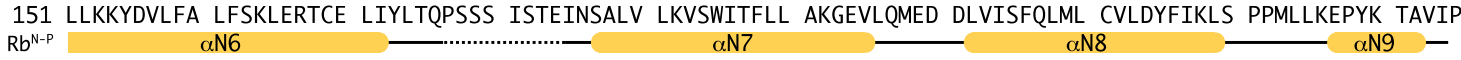

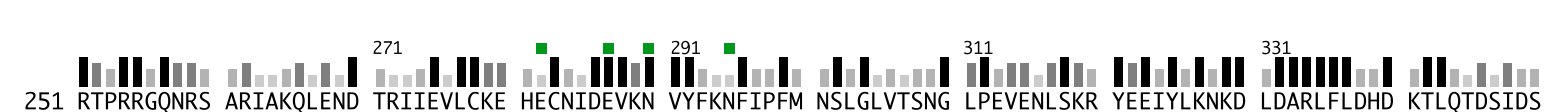
251 RTPRRGQNRS ARIAKQLEND TRIIEVLCKE HECNIDEVKN VYFKNFIPFM NSLGLVTSNG LPEVENLSKR YEEIYLKNKD LDARLFLDHD KTLQTDSIDS
$\mathrm{Rb} b^{W-P}$

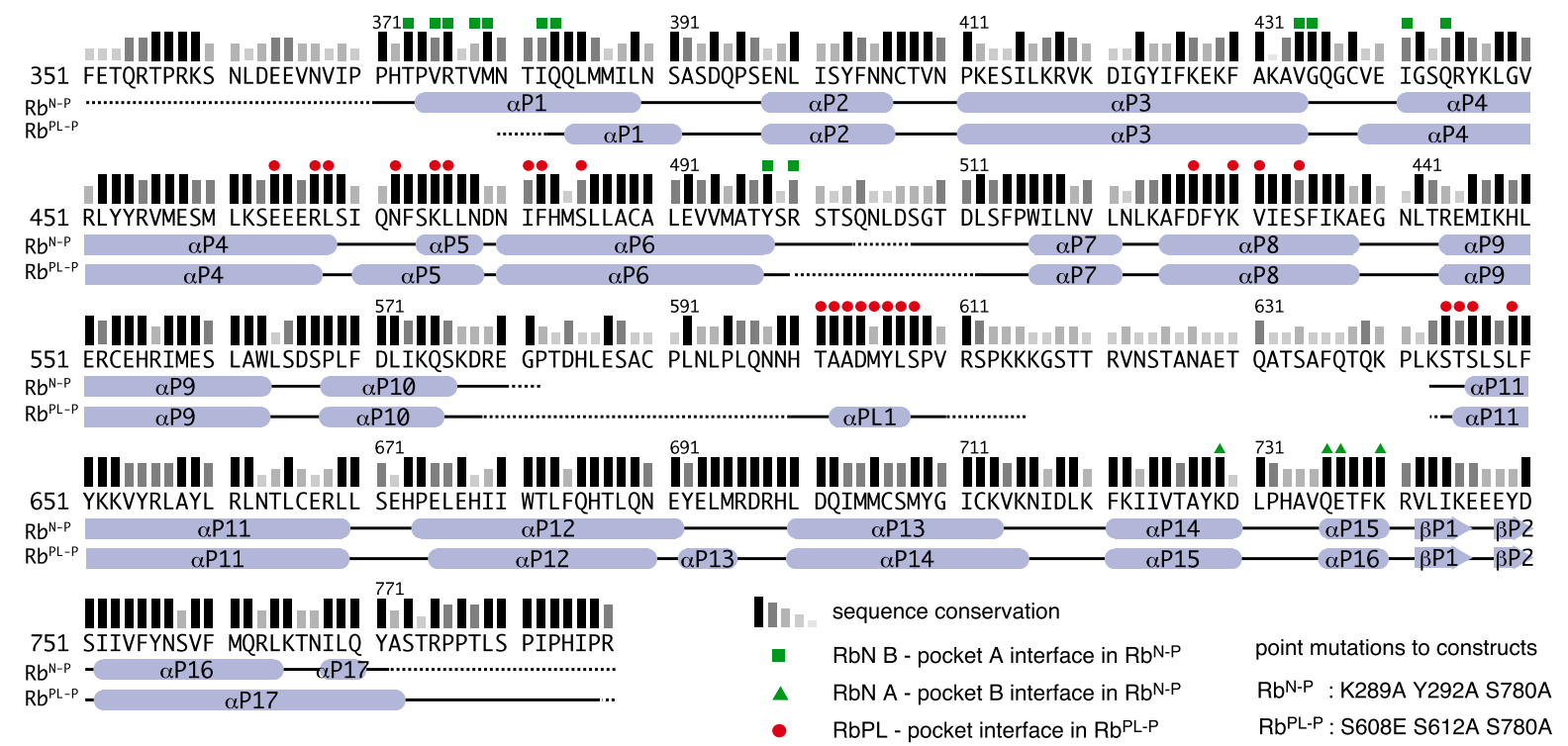

Figure 3. Summary of Rb crystal structures and interdomain interactions. Rb sequence conservation and secondary structure analysis. The bottom secondary structure markings are assigned from the $\mathrm{Rb}^{\mathrm{PL}-\mathrm{P}}$ structure (Fig. 2), and the top markings are assigned from the $\mathrm{Rb}^{\mathrm{N}-\mathrm{P}}$ structure (Fig. 4). Residues that make interdomain contacts in each crystal structure are indicated. The degree of conservation is based on alignment of the human, mouse, chicken, frog, and zebrafish sequences.

bridge with K164, which is found on the long helix $(\alpha \mathrm{N} 6)$ that connects the two RbN subdomains (Hassler et al. 2007). The phosphate also makes an N-terminal helixcapping interaction in the first helix of the pocket domain $(\alpha \mathrm{P} 1)$. The phosphate oxygens serve as hydrogen bond acceptors to backbone amide protons from R376 and V375 (Fig. 4B). This capping stabilizes $\alpha \mathrm{P} 1$ such that two extra turns at its $\mathrm{N}$ terminus are ordered relative to the unphosphorylated structure (Fig. 3; Lee et al. 1998). These two turns position V375 and M379 to pack against RbN L161 and a conserved patch of hydrophobic residues (L212, V213, and F216), which were previously suggested to constitute a protein interaction surface in RbN (Figs. 3, 4B; Hassler et al. 2007). The C-terminal half of the $\alpha \mathrm{P} 1$ helix packs against the pocket domain, with residues I382 and L385 forming a hydrophobic interface with V494, T497, and Y498. In sum, T373 phosphorylation lengthens the $\alpha \mathrm{P} 1$ helix and positions it to form an interface with $\mathrm{RbN}$, holding both domains in the docked conformation.

The second interdomain interface is between pocket subdomain $\mathrm{B}$ and $\mathrm{RbN}$ subdomain $\mathrm{A}$ (Fig. 4). This smaller interface ( $387 \AA^{2}$ buried surface area) is formed exclusively by polar contacts from highly conserved residues (Figs. 3, 4C). Q736 from the pocket makes a side chain hydrogen bond with D145; the latter reaches the interface from the N-terminal end of the RbN-bridging helix $\alpha \mathrm{N} 6$. K740 makes a hydrogen bond with the backbone carbonyl T140 and a salt bridge with D139 in RbN. K740 is part of the previously identified "lysine patch," a set of conserved lysine residues in pocket subdomain B thought to play a role in binding phosphorylated $\mathrm{RbC}$ (Harbour et al. 1999; Rubin et al. 2005; Singh et al. 2005).

Electron density corresponding to phosphorylated T356 was not present in the $\mathrm{Rb}^{\mathrm{N}-\mathrm{P}}$ crystal structure. Helix $\alpha \mathrm{N} 13$, which immediately precedes T356 and is present in the structure of $\mathrm{RbN}$ alone (Hassler et al. 2007), is also not observable here (Fig. 3). One possible explanation for the disordering of $\alpha \mathrm{N} 13$ in $\mathrm{Rb}^{\mathrm{N}-\mathrm{P}}$ is that T356 phosphorylation has a destabilizing effect at the electrostatically negative helix C terminus. Calorimetry and SAXS experiments confirm that T373, but not T356, is primarily responsible for the $\mathrm{E}^{\mathrm{T}} \mathrm{TD}^{\mathrm{TD}}$ inhibition and interdomain association effects induced by RbIDL phosphorylation (Supplemental 


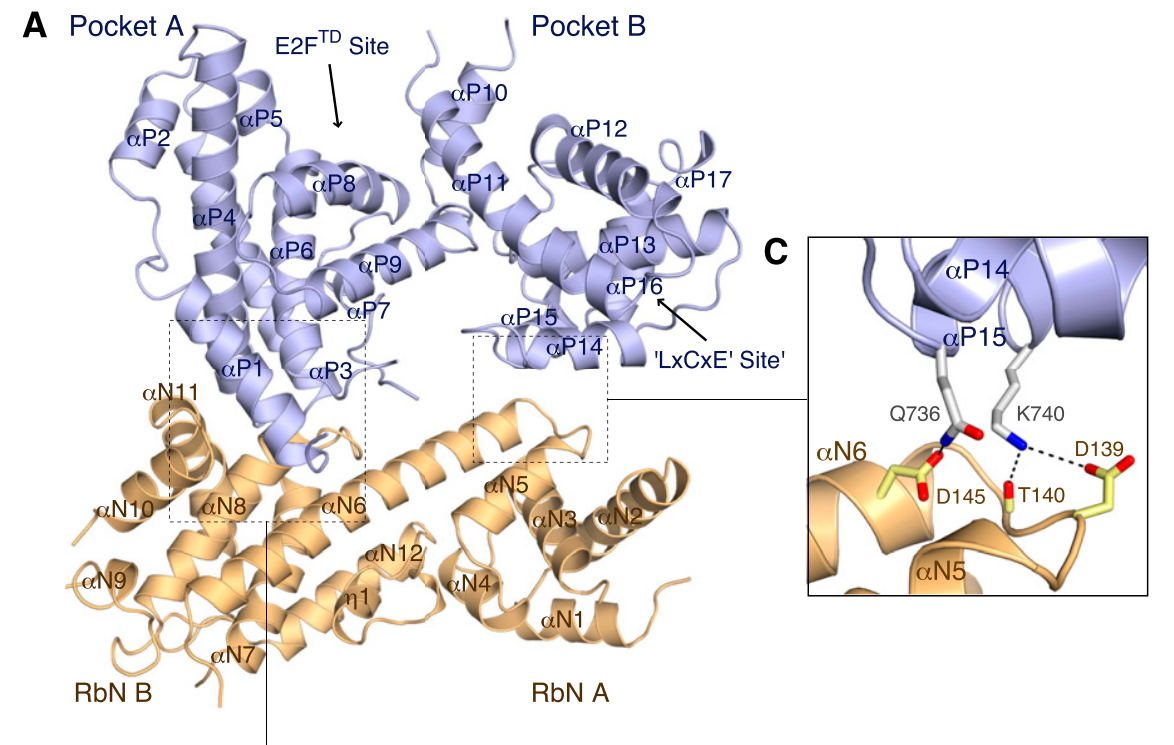

B

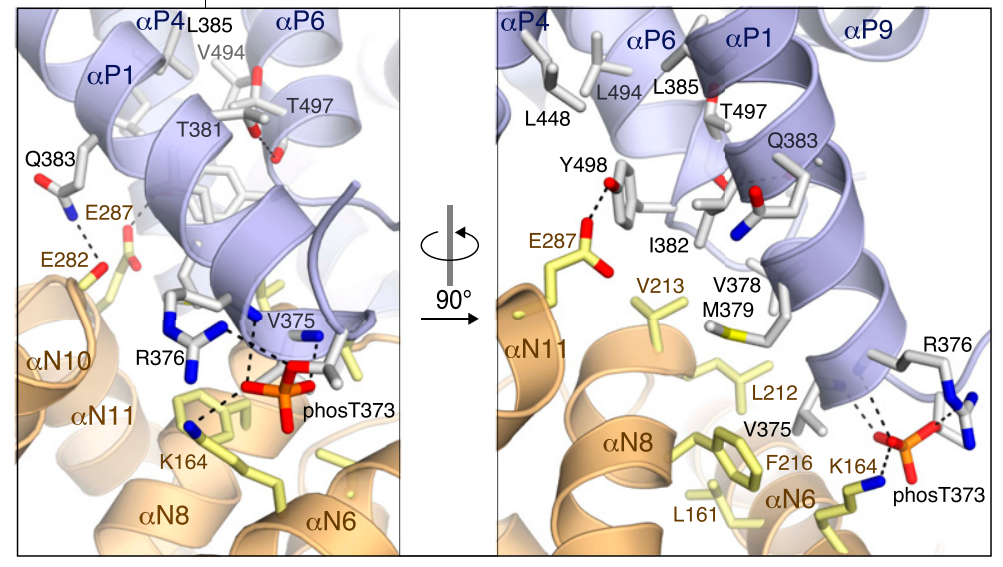

Figure 4. Structure of the phosphorylated $\mathrm{RbN}$-pocket complex. $(A)$ Overall structure of $\mathrm{Rb}^{\mathrm{N}-\mathrm{P}}$. $\mathrm{RbN}$ and the pocket domain are colored gold and blue, respectively. $(B)$ The interface between pocket subdomain $\mathrm{A}$ and $\mathrm{RbN}$ subdomain $\mathrm{B}$ is mediated by T373 phosphorylation. Phosphothreonine T373 directly contacts K164 and orders the two N-terminal turns of helix $\alpha \mathrm{P} 1$, which form a hydrophobic interface with $\mathrm{RbN}$. $(C)$ The interface between pocket subdomain $\mathrm{B}$ and $\mathrm{RbN}$ subdomain $\mathrm{A}$ is mediated by pocket residues Q736 and K740.
Figs. 2, 3). Accordingly, the function of the structural change that occurs upon T356 phosphorylation is not yet clear.

\section{T373 phosphorylation induces RbN-pocket docking}

The $\mathrm{Rb}^{\mathrm{N}-\mathrm{P}}$ structure suggests that $\mathrm{T} 373$ phosphorylation is essential for the $\mathrm{RbN}$ and pocket domain association. This observation raises the question of whether the domains are undocked in the unphosphorylated state. To explore the conformation of $\mathrm{Rb}$ in the unphosphorylated state and test whether RbIDL phosphorylation induces a significant conformational change in solution, we used SAXS (Putnam et al. 2007). SAXS curves for the unphosphorylated and phosphorylated $\mathrm{Rb}^{\Delta \mathrm{Loops}}$ are notably distinct, and the phosphorylated protein has a smaller radius of gyration $\left(\mathrm{R}_{\mathrm{g}}{ }^{\text {unphos }}=36.8 \AA\right.$ and $\left.\mathrm{R}_{\mathrm{g}}{ }^{\text {phos }}=31.7 \AA\right)$ (Fig. 5A). Shapes calculated from the SAXS curves reflect this change in $\mathrm{R}_{\mathrm{g}}$ and suggest a conformational change from an extended to a compact structure upon phosphorylation.

Analysis of the Porod-Debye region of the SAXS curves indicates that T373 phosphorylation induces structural ordering within $\mathrm{Rb}$ (Fig. 5B). SAXS intensities from com- pact structures decay as $\mathrm{q}^{4}$ in intermediate resolution regions of the curve, and in a plot of $\mathrm{I}(\mathrm{q}){ }^{*} \mathrm{q}^{4}$, compact structures plateau (Rambo and Tainer 2011). In contrast, unfolded proteins decay as $\mathrm{q}^{2}$ and do not plateau in the $\mathrm{I}(\mathrm{q})^{\star} \mathrm{q}^{4}$ plot. Data for only the phosphorylated $\mathrm{Rb}^{\Delta \text { Loops }}$ show the characteristic plateau (see $\sim 0.08 \AA^{-1}$ ) of a compact structure. The Porod-Debye decay of the phosphorylated state is best fit by an exponent of 3.9, which is close to the value of 4 for a compact, globular protein. The curve for the unphosphorylated state decays with an exponent of 3.3, which is consistent with the presence of a significant structural disorder in the unphosphorylated state.

We further analyzed the $\mathrm{Rb}^{\Delta \text { Loops }}$ SAXS data by comparison with theoretical curves calculated from atomic models based on the $\mathrm{Rb}^{\mathrm{N}-\mathrm{P}}$ crystal structure. A complete atomic model for $\mathrm{Rb}^{\Delta \mathrm{Loops}}$ was first generated in which flexible loops not visible in the electron density were built in using Modeller (Supplemental Fig. 4). A large ensemble of possible solution conformations was then generated with a molecular dynamics simulation. The conformations in the ensemble whose calculated scattering curves best fit the experimental data for phosphorylated $\left(\chi^{2}=1.4\right)$ and unphosphorylated $\left(\chi^{2}=1.6\right)$ are shown in Figure 5A. 
A

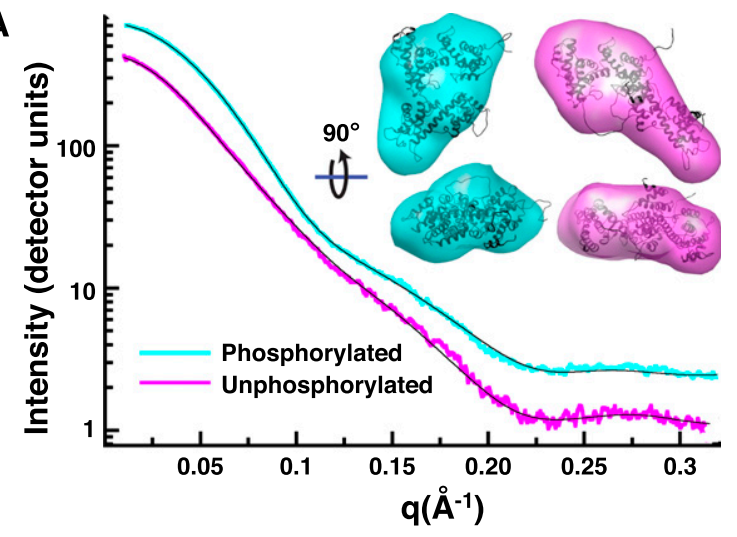

B

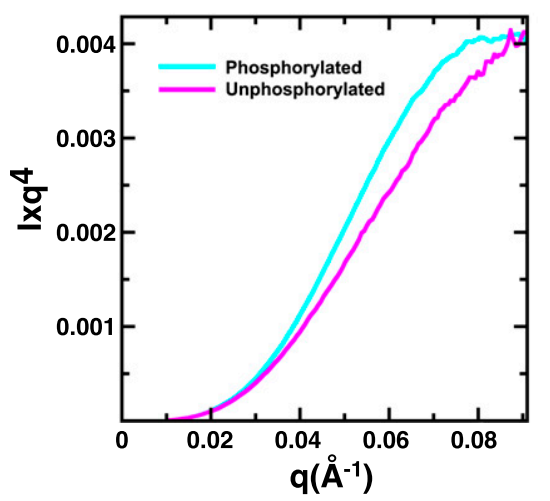

Figure 5. RbIDL phosphorylation induces $\mathrm{RbN}$-pocket docking. (A) SAXS data from phosphorylated (cyan) and unphosphorylated (magenta) $\mathrm{Rb}^{\Delta \text { Loops }}$. Envelopes calculated from the SAXS curves are shown in the inset. Models based on the $\mathrm{Rb}^{\mathrm{N}-\mathrm{P}}$ crystal structure that best fit the SAXS data are shown as black ribbons within the envelopes. The calculated scattering curves of the best models are shown as black lines through the SAXS data. $(B)$ Porod-Debye region of the experimental scattering curves for phosphorylated (cyan) and unphosphorylated (magenta) $\mathrm{Rb}^{\Delta \text { Loops }}$. The plateau of the phosphorylated curve indicates an ordered, compact structure.

The single best-fitting model to the phosphorylated state is similar to the Modeller structure and has the same $\mathrm{R}_{\mathrm{g}}$ and $\mathrm{D}_{\max }$. The best-fitting model to the unphosphorylated state has the two domains undocked, consistent with the larger $\mathrm{R}_{\mathrm{g}}$ and the role of phosT373 in creating the $\mathrm{RbN}-$ pocket interface observed in the $\mathrm{Rb}^{\mathrm{N}-\mathrm{P}}$ structure.

While these best-fitting models are plausible solution conformations, equivalent fits may exist with $\mathrm{Rb}$ in an ensemble of states, with no single structure representing the entire population. Using a minimal ensemble approach, we found that the unphosphorylated data are best fit by an ensemble of both undocked and docked structures, while the phosphorylated data are best fit by predominately docked structures $\left(\chi^{2}=1.0\right.$ for both) (Supplemental Fig. 4). This analysis suggests an equilibrium between associated and dissociated $\mathrm{RbN}$ and pocket domains, in which phosphorylation of RbIDL shifts the equilibrium toward the associated conformation. The presence of a small population of associated molecules even in the unphosphorylated state is consistent with previous observations of a weak
$\mathrm{RbN}$-pocket association that is phosphorylation-independent (Hassler et al. 2007).

\section{$R b N$-pocket docking inhibits protein binding at the pocket LxCXE site}

The $\mathrm{RbN}$ docking in pocket subdomain $\mathrm{B}$ is proximal to the LxCxE-binding cleft, which is a well-characterized binding site for cellular and viral proteins as well as phosphorylated RbC (Harbour et al. 1999; Rubin et al. 2005; Singh et al. 2005). Alignment of the $\mathrm{Rb}^{\mathrm{N}-\mathrm{P}}$ structure with the pocket structure bound by the $\mathrm{E} 7 \mathrm{LxCxE}$ peptide shows some steric clashing between $\mathrm{RbN}$ subdomain $\mathrm{A}$ and the LxCxE peptide (data not shown). With a quantitative binding assay, we tested whether T356/T373 phosphorylation, which drives $\mathrm{RbN}$-pocket docking, inhibits the affinity of peptides known to associate at the LxCxE cleft (Table 2; Supplemental Fig. 5). Using the $\mathrm{Rb}^{\triangle \mathrm{Loops}, \mathrm{S} 780 \mathrm{~A}}$ construct, which only contains the RbIDL sites, we found that the affinity of the LxCxE peptide from E7 for phosphorylated protein $\left(\mathrm{K}_{\mathrm{d}}=0.8 \pm 0.2 \mu \mathrm{M}\right)$ is weaker than its affinity for unphosphorylated protein $\left(\mathrm{K}_{\mathrm{d}}=0.12 \pm 0.06 \mu \mathrm{M}\right)$. We also found a similar weak affinity for a phosphorylated construct that contains all of the $\mathrm{RbN}$, RbIDL, and pocket phosphorylation sites $\left(\mathrm{Rb}^{55-787} ; \mathrm{K}_{\mathrm{d}}=1.1 \pm 0.1 \mu \mathrm{M}\right)$. E7 binding to the pocket domain phosphorylated on S608/S612 $\left(\mathrm{K}_{\mathrm{d}}=0.14 \pm 0.01 \mu \mathrm{M}\right)$ is similar to that previously reported for the unphosphorylated pocket domain $\left(\mathrm{K}_{\mathrm{d}}=0.11 \pm 0.03 \mu \mathrm{M}\right)$ (Lee et al. 1998), indicating that phosphorylation of RbPL sites does not inhibit $\mathrm{LxCxE}$ binding to the pocket. Finally, we found that phosphorylation of T373 is necessary for inhibition of LxCxE binding, as the affinity of E7 peptide for a phosphorylated T373A mutant (phosRb ${ }^{\Delta \text { Loops,T373A,S780A; }}$ $\mathrm{K}_{\mathrm{d}}=0.29 \pm 0.07 \mu \mathrm{M}$ ) is more similar to its affinity for unphosphorylated $\mathrm{Rb}\left(\mathrm{Rb}^{\Delta \text { Loops, } \mathrm{S} 780 \mathrm{~A}} ; \mathrm{K}_{\mathrm{d}}=0.12 \pm 0.06 \mu \mathrm{M}\right)$. This result is consistent with the observation that T373 phosphorylation, but not T356 phosphorylation, is necessary and sufficient for RbN-pocket docking (Supplemental Figs. 2, 3).

Phosphorylation of $\mathrm{RbC}$ at $\mathrm{T} 821 / \mathrm{T} 826$ induces binding to the pocket domain at a site that overlaps with the LxCxE site and potentially involves the lysine patch in pocket subdomain B (Harbour et al. 1999; Rubin et al. 2005). Considering the proximity of the docked $\mathrm{RbN}$ subdomain $\mathrm{A}$ to this site in the $\mathrm{Rb}^{\mathrm{N}-\mathrm{P}}$ structure (Fig. 4), we next tested whether RbIDL phosphorylation also inhibits phosRbC binding to the pocket (Table 2; Supplemental Fig. 5). $\mathrm{Rb}^{771-928}$, which includes $\mathrm{RbC}$ and seven $\mathrm{Cdk}$ consensus sites (S780, S788, S795, S807, S811, T821, and T826), was quantitatively phosphorylated and mixed with $\mathrm{Rb}^{\mathrm{N}-\mathrm{P}}$ in the calorimetry assay. We found that the affinity of phosRb ${ }^{771-928}$ was similar for unphosphorylated $\left(\mathrm{K}_{\mathrm{d}}=\right.$ $20 \pm 4 \mu \mathrm{M})$ and phosphorylated $\mathrm{Rb}^{\mathrm{N}-\mathrm{P}}\left(\mathrm{K}_{\mathrm{d}}=25 \pm 13 \mu \mathrm{M}\right)$. Both of these values are similar to that previously reported for a comparable phosRbC construct binding to the pocket domain (Rubin et al. 2005). The affinity of a synthetic peptide containing phosphorylated T821 and T826 to phosphorylated $\mathrm{Rb}^{\mathrm{N}-\mathrm{P}}\left(\mathrm{K}_{\mathrm{d}}=11 \pm 2 \mu \mathrm{M}\right)$ is also similar to that previously reported for an unphosphory- 
Table 2. T373 phosphorylation inhibits binding of E7 but not phosRbC at the pocket LxCxE site

\begin{tabular}{llrr}
\hline $\mathrm{Rb}$ construct & \multicolumn{1}{c}{ Phosphorylated Cdk sites } & Binding protein & $\mathrm{K}_{\mathrm{d}}$ \\
\hline $\mathrm{Rb}^{\text {LLoops,S780A }}$ & None & E7 LxCxE & $0.12 \mu \mathrm{M} \pm 0.06 \mu \mathrm{M}$ \\
$\mathrm{Rb}^{\text {LLoops,S780A }}$ & T356, T373 & E7 LxCxE & $0.8 \mu \mathrm{M} \pm 0.2 \mu \mathrm{M}$ \\
$\mathrm{Rb}^{55-787}$ & S249, T252, T356, T373, S608, S612 & E7 LxCxE & $1.1 \mu \mathrm{M} \pm 0.1 \mu \mathrm{M}$ \\
$\mathrm{Rb}^{379-792}$ & None & E7 LxCxE & $0.11 \mu \mathrm{M} \pm 0.03 \mu \mathrm{M}^{\mathrm{a}}$ \\
$\mathrm{Rb}^{380-787}$ & $\mathrm{~S} 608, \mathrm{~S} 612$ & E7 LxCxE & $0.14 \pm 0.01$ \\
$\mathrm{Rb}^{\text {LLoops,T373A,S780A }}$ & $\mathrm{T} 356$ & E7 LxCxE & $0.29 \mu \mathrm{M} \pm 0.07 \mu \mathrm{M}$ \\
$\mathrm{Rb}^{\mathrm{N}-\mathrm{P}}$ & None & phosRb771-928 & $20 \mu \mathrm{M} \pm 4 \mu \mathrm{M}$ \\
$\mathrm{Rb}^{\mathrm{N}-\mathrm{P}}$ & $\mathrm{T} 356, \mathrm{~T} 373$ & phosRb771-928 & $25 \mu \mathrm{M} \pm 13 \mu \mathrm{M}$ \\
$\mathrm{Rb}^{373-787}$ & None & phosRb786-874 & $8 \mu \mathrm{M} \pm 4 \mu \mathrm{M}^{\mathrm{b}}$ \\
$\mathrm{Rb}^{\mathrm{N}-\mathrm{P}}$ & T356, T373 & phosRb818-842 & $11 \mu \mathrm{M} \pm 2 \mu \mathrm{M}$ \\
$\mathrm{Rb}^{373-787}$ & None & phosRb818-839 & $7 \mu \mathrm{M} \pm 1 \mu \mathrm{M}^{\mathrm{b}}$ \\
\hline
\end{tabular}

Isothermal titration calorimetry (ITC)-measured binding affinities for similar experiments using E7 LxCxE peptides and phosRbC. Sample ITC curves are shown in Supplemental Figure 5.

${ }^{a}$ Measurements reported in Lee et al. (1998).

${ }^{\mathrm{b}}$ Measurements reported in Rubin et al. (2005).

lated pocket domain $\left(\mathrm{K}_{\mathrm{d}}=7 \pm 1 \mu \mathrm{M}\right)$ (Rubin et al. 2005). These measurements indicate that RbIDL phosphorylation and the corresponding domain closure do not affect binding of phosRbC to the pocket domain. We conclude that the $\mathrm{RbN}$ - and phosRbC-binding sites in the $\mathrm{Rb}$ pocket are not exclusive and that these domains may regulate different protein-protein interactions involving pocket subdomain $\mathrm{B}$.

\section{RbN-pocket docking allosterically inhibits $E 2 F^{T D}$ binding}

$\mathrm{RbN}$ binds the pocket domain on the face opposite from E2 $\mathrm{F}^{\mathrm{TD}}$ (Fig. 4), suggesting that direct competition is not the mechanism by which RbIDL phosphorylation inhibits the $\mathrm{Rb}-\mathrm{E} 2 \mathrm{~F}$ complex. Instead, comparison between this $\mathrm{Rb}^{\mathrm{N}-\mathrm{P}}$ structure and structures of the pocket with E2 $\mathrm{F}^{\mathrm{TD}}$ bound reveals that $\mathrm{T} 373$ phosphorylation inhibits $\mathrm{E} 2 \mathrm{~F}^{\mathrm{TD}}$ binding through an allosteric mechanism. RbN docking to the pocket induces a relative rotation of the pocket $\mathrm{A}$ and $\mathrm{B}$ subdomains by $9.6^{\circ}$ about an axis that bisects them. To better visualize how this structural change is inconsistent with tight $\mathrm{E}^{\mathrm{F}} \mathrm{F}^{\mathrm{TD}}$ binding, we aligned the A subdomains of $\mathrm{Rb}^{\mathrm{N}-\mathrm{P}}$ and the pocket-E2F $\mathrm{F}^{\mathrm{TD}}$ structure (Protein Data Bank [PDB]: 1N4M) (Fig. 6). In this alignment, contacts between $\mathrm{E} 2 \mathrm{~F}^{\mathrm{TD}}$ and residues in pocket $\mathrm{A}$ of $\mathrm{Rb}^{\mathrm{N}-\mathrm{P}}$ can be maintained; however, distances to several residues in pocket $\mathrm{B}$ are too far for proper binding. For example, K652 is translated $2.5 \AA$ away from its position in the pocket-E2 $\mathrm{F}^{\mathrm{TD}}$ structure (relative $C_{\alpha}$ position) and is too distant to make its requisite interactions (Fig. 6B; Supplemental Fig. 6).

The $\mathrm{Rb}^{\mathrm{N}-\mathrm{P}}$ structure suggests two features that are likely critical for the observed rotation of the pocket subdomains. First, RbN binding can influence the relative orientation of pockets $\mathrm{A}$ and $\mathrm{B}$ because both subdomains are contacted in forming the overall interface. Second, the relative orientation of the $\mathrm{RbN}$ subdomains remains fixed upon pocket docking, likely because of the rigidity of the unique RbN-bridging helix $(\alpha \mathrm{N} 6)$ (Figs. 4A, 6A; Hassler et al. 2007). Residues on both ends of the same $\alpha \mathrm{N} 6$ helix, K164 and D145, make respective contacts at each of the pocket subdomain A and B interfaces, providing a constraint to the pocket subdomain geometry required for the overall $\mathrm{RbN}$ association. To support the allosteric model for $\mathrm{E}^{\mathrm{TD}}$ inhibition suggested by the structure, we tested E2 $\mathrm{F}^{\mathrm{TD}}$ binding to an $\mathrm{Rb}^{\Delta \mathrm{Loops}}$ construct in which Q736 and K740-two residues in pocket domain $\mathrm{B}$ that make critical contacts at the smaller, polar $\mathrm{RbN}$ interface (Fig. 4C) - are mutated to alanine. We found that phosphorylation of this mutant protein does not weaken E2F ${ }^{\mathrm{TD}}$ affinity (Supplemental Fig. 6), confirming the requirement of both interfaces for the inhibitory pocket domain conformation.

\section{Discussion}

Our results demonstrate the phosphorylation-induced structural changes in $\mathrm{Rb}$ that result in loss of $\mathrm{E} 2 \mathrm{~F}^{\mathrm{TD}}$ affinity. The crystal structures together specifically implicate T373 and S608 as the key phosphorylation events for $\mathrm{E} 2 \mathrm{~F}^{\mathrm{TD}}$ inhibition. These observations are consistent with assays for E2F binding and $\mathrm{Rb}$ inactivation in cancer cell models that found critical phosphorylation events in RbPL and RbIDL (Knudsen and Wang 1997; Zarkowska and Mittnacht 1997; Brown et al. 1999; Lents et al. 2006; Gorges et al. 2008). In particular, the importance of T373 phosphorylation in the mechanism of $\mathrm{Rb}$ inactivation is supported by the observation that only T373 phosphorylation is sufficient for E2F dissociation and activation in cells (Lents et al. 2006; Gorges et al. 2008). The $\mathrm{Rb}^{\mathrm{N}-\mathrm{P}}$ structure and SAXS data also explain the critical role for $\mathrm{RbN}$ in $\mathrm{Rb}$ inactivation previously suggested by cellular assays (Knudsen and Wang 1997). RbN docking to the pocket, which is stimulated by T373 phosphorylation, induces a change in the relative pocket subdomain orientation that perturbs the E2F-binding site.

We found that T373 and S608 phosphorylation stimulate distinct and independent mechanisms for decreasing $\mathrm{E} 2 \mathrm{~F}^{\mathrm{TD}}$ binding, explaining how multisite $\mathrm{Rb}$ phosphorylation cumulatively induces Rb-E2F inhibition and E2F activation (Brown et al. 1999; Burke et al. 2010). T373 phosphorylation and $\mathrm{RbN}$ docking disrupt the pocket 
A

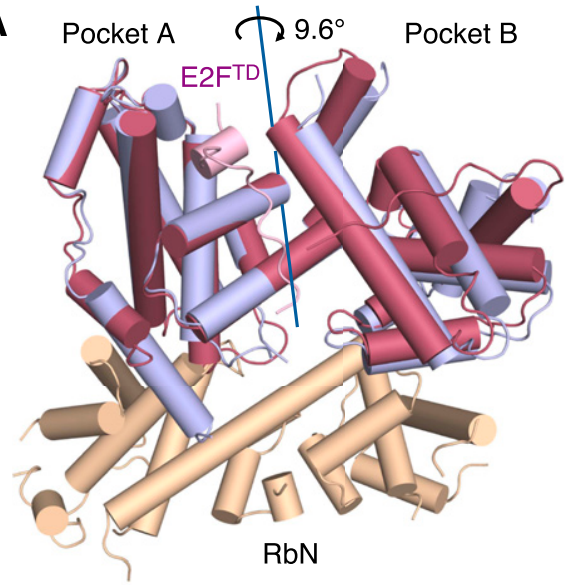

B

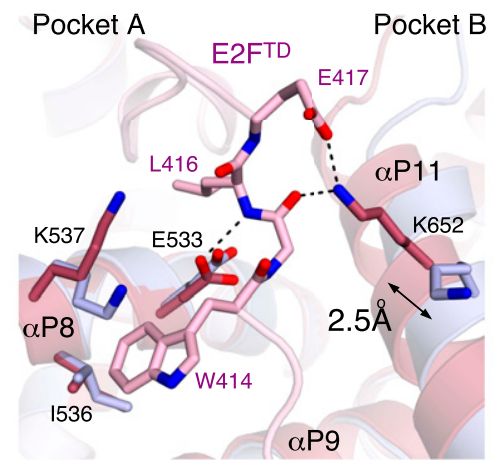

Figure 6. Structural change in the pocket domain induced by $\mathrm{RbN}$ binding and its effect on the $\mathrm{E} 2 \mathrm{~F}^{\mathrm{TD}}$-binding site. (A) Structural comparison of $\mathrm{Rb}^{\mathrm{N}-\mathrm{P}}$ (gold and blue) with the $\mathrm{E}^{2} \mathrm{~F}^{\mathrm{TD}}$-bound pocket domain (red, PDB: $1 \mathrm{~N} 4 \mathrm{M}$ ), generated by aligning the pocket subdomain A of each structure. The pocket subdomain $\mathrm{B}$ of $\mathrm{Rb}^{\mathrm{N}-\mathrm{P}}$ is rotated by $9.6^{\circ}$ relative to the $\mathrm{E} 2 \mathrm{~F}^{\mathrm{TD}}$-pocket subdomain $\mathrm{B}$. (B) Close-up of the $\mathrm{E} 2 \mathrm{~F}^{\mathrm{TD}}$-binding cleft in the same structural alignment as in $A$. The subdomain orientation induced by $\mathrm{RbN}$ docking is incompatible with optimal $\mathrm{E} 2 \mathrm{~F}^{\mathrm{TD}}$ binding. For example, in this alignment, pocket A residues (E533, I536, and $\mathrm{K} 537$ ) can contact $\mathrm{E} 2 \mathrm{~F}^{\mathrm{TD}}$, but the position of $\mathrm{K} 652$ in subdomain $\mathrm{B}$ of $\mathrm{Rb}^{\mathrm{N}-\mathrm{P}}$ is too distant.

structure at the overlapping $\mathrm{E} \mathrm{F}^{\mathrm{TD}}$ - and phosRbPLbinding site, yet do not abrogate the inhibitory effect of S608 phosphorylation on E2F ${ }^{\mathrm{TD}}$ binding (Burke et al. 2010). We suggest that while $\mathrm{RbN}$ docking likely weakens the association of phosRbPL as well as $\mathrm{E}_{2} \mathrm{~F}^{\mathrm{TD}}$ to the pocket, phosRbPL is still present as a competitive inhibitor to reduce the apparent $\mathrm{E} 2 \mathrm{~F}^{\mathrm{TD}}$ affinity further.

Together with previous studies characterizing the effects of phosphorylation in RbC (Knudsen and Wang 1997; Harbour et al. 1999; Rubin et al. 2005), our results demonstrate that specific phosphorylation events generate remarkably diverse structural changes in $\mathrm{Rb}$. In several cases, phosphorylation takes place in an intrinsically disordered region of the protein and induces structure formation. T373 phosphorylation in RbIDL induces pocket-RbN docking, S608 phosphorylation induces RbPL binding to the pocket domain, and T821/T826 phosphorylation induces $\mathrm{RbC}$ association with the pocket domain (Rubin et al. 2005). In two other cases, there is evidence that phosphorylation induces the surrounding sequence to undergo a structured-to-disordered transition. S788/S795 phosphorylation directly inhibits binding of part of RbC to the E2F-DP marked box domains (Rubin et al. 2005), and here we observe that T356 phosphorylation disorders a helix in $\mathrm{RbN}$. Now that these independent structural changes have been characterized, it will be important to investigate how they are coordinated to generate different cellular effects.

The differences in the two inhibitory mechanisms described here offer new insights into the importance of diverse phosphorylation pathways leading to $\mathrm{Rb}$ inactivation. It is noteworthy that phosphorylated RbPL directly competes with $\mathrm{E} 2 \mathrm{~F}^{\mathrm{TD}}$ for pocket binding, while phosphorylation-induced $\mathrm{RbN}$ docking weakens $\mathrm{E} 2 \mathrm{~F}^{\mathrm{TD}}$ affinity through an allosteric interaction. Direct RbPL competition for binding is an efficient mechanism for inhibiting E2F complex formation, but likely not for dislodging E2F that is already tightly bound. The allosteric mechanism in which phosT373-induced RbN docking opens the E2Fbinding site is better suited for dissociating preformed $\mathrm{Rb}-$ E2F complexes. These distinct mechanisms for E2F inhibition may be relevant and used depending on the particular cellular context. Interestingly, the observation of an allosteric interaction mediating E2F release suggests the possibility of therapeutically targeting the RbNpocket interface to prevent $\mathrm{Rb}$ inactivation.

The particular $\mathrm{Rb}$ conformations that result from distinct phosphorylation events differ in their ability to bind other protein factors. We found here that in addition to reducing E2F affinity, T373 phosphorylation uniquely inhibits binding at the LxCxE site. We propose that an additional important role for multisite phosphorylation in E2F inhibition is that distinct phosphorylations differentially modulate other $\mathrm{Rb}$ complexes. This function of multisite phosphorylation in cell cycle signaling is novel compared with previous well-characterized examples in which the enzymatic mechanisms of multisite phosphorylation tune the signaling properties of a single output (Nash et al. 2001; Kim and Ferrell 2007; Koivomagi et al. 2011). Here, the structural diversity of different Rb phosphoforms supports a model in which multisite Cdk phosphorylation generates multiple signaling outputs by assembling distinct protein complexes.

\section{Materials and methods}

\section{Protein production and binding assays}

Proteins were overexpressed in Escherichia coli as fusions with glutathione $S$-transferase. Proteins were purified by glutathione affinity chromatography, followed by cation exchange chromatography. Quantitative phosphorylation of purified protein was achieved with $2 \%$ Cdk6-CycK or $10 \%$ Cdk2-CycA overnight at $4^{\circ} \mathrm{C}$. Phosphate incorporation was verified by electrospray mass spectrometry. Detailed procedures for protein expression, purification, phosphorylation, and isothermal titration calorimetry (ITC) experiments were previously described (Burke et al. 2010). Reported $\mathrm{K}_{\mathrm{d}}$ values are the average of two to three ITC experiments, and the standard deviation of the mean is reported as the error. 
Crystallization, $X$-ray data collection, structure determination, and model refinement

Proteins were prepared for crystallization by elution from a Superdex 200 column in a buffer containing $25 \mathrm{mM}$ Tris, 200 $\mathrm{mM} \mathrm{NaCl}$, and $5 \mathrm{mM}$ DTT. Proteins were crystallized by sitting drop vapor diffusion at $4^{\circ} \mathrm{C}$. $\mathrm{Rb}^{\mathrm{PL}-\mathrm{P}}$ crystals grew for 1 wk in a solution containing $100 \mathrm{mM}$ sodium citrate, $1 \mathrm{M} \mathrm{LiCl}$, and $18 \%$ PEG $8 \mathrm{~K}(\mathrm{pH} 5.5)$ and were frozen in the same solution with $30 \%$ ethylene glycol. $\mathrm{Rb}^{\mathrm{N}-\mathrm{P}}$ crystals grew for $3 \mathrm{wk}$ in a solution containing $100 \mathrm{mM}$ HEPES, $100 \mathrm{mM}$ ammonium fluoride, and $16 \%$ PEG 4K (pH 6.5) and were frozen in the same solution with $30 \%$ ethylene glycol.

Data were collected on Beamline 7.1 at the Stanford Synchrotron Radiation Lightsource $\left(\mathrm{Rb}^{\mathrm{PL}-\mathrm{P}}\right)$ and on Beamline $23-\mathrm{IDB}$ at the Advanced Photon Source, Argonne National Laboratory $\left(\mathrm{Rb}^{\mathrm{N}-\mathrm{P}}\right)$. Diffraction spots were integrated with Mosflm (Leslie 2006) and scaled with SCALE-IT (Howell and Smith 1992). Phases were solved by molecular replacement using PHASER (Mccoy et al. 2007). For $\mathrm{Rb}^{\mathrm{PL}-\mathrm{P}}$, the unliganded $\mathrm{Rb}$ pocket (PDB ID: $3 \mathrm{POM}$ ) was used as a search model, and the unliganded pocket and $\mathrm{RbN}$ (2QDJ) were used as search models for $\mathrm{Rb}^{\mathrm{N}-\mathrm{P}}$. The initial model was rebuilt with Coot (Emsley and Cowtan 2004) and was refined with Phenix (Adams et al. 2010). Several rounds of position refinement with simulated annealing and individual temperature factor refinement with default restraints were applied. The $\mathrm{Rb}^{\mathrm{PL}-\mathrm{P}}$ structure has two molecules in the asymmetric unit, while the $\mathrm{Rb}^{\mathrm{N}-\mathrm{P}}$ molecule has one. In one of the asymmetric unit molecules in $\mathrm{Rb}^{\mathrm{PL}-\mathrm{P}}$, residues $579-589$ extend to a crystallographic symmetry mate and contact its LxCxE-binding site. Considering that these residues are not well conserved, that the $\mathrm{Rb}$ pocket is a monomer in solution (size exclusion chromatography and SAXS) (data not shown), and that other pocket crystal structures show nonspecific crystallographic interactions at this site (Lee et al. 2002; Liu and Marmorstein 2007), we believe that this observed association is a crystallographic packing artifact. Water was modeled into the electron density using Phenix with default parameters. An electron density feature corresponding to two to three water molecules is visible at the smaller $\mathrm{RbN}$-pocket interface in $\mathrm{Rb}^{\mathrm{N}-\mathrm{P}}$. We had difficulty refining water at this site, perhaps due to heterogeneity in the precise water geometry throughout the crystal, and left the density unmodeled. Buried surface areas were calculated using Chimera (Pettersen et al. 2004), and the pocket subdomain rotation was calculated using the program DynDom (Hayward and Berendsen 1998). Coordinates and structure factors have been deposited in $\mathrm{PDB}$ for $\mathrm{Rb}^{\mathrm{PL}-\mathrm{P}}$ and $\mathrm{Rb}^{\mathrm{N}-\mathrm{P}}$ under accession codes 4ELL and 4ELJ, respectively.

\section{SAXS and analysis}

SAXS data were collected at the SIBYLS beamline (12.3.1) at the Advanced Light Source, Lawrence Berkeley National Laboratory. Scattering data are plotted as a function of $q=4 \pi[\sin (\theta / 2)] / \lambda$, where $\theta$ is the scattering angle, and $\lambda$ is the $\mathrm{X}$-ray wavelength in angstroms. An automated pipeline was applied for collection and partial analysis as previously described (Hura et al. 2009). Three concentrations of each sample were collected with three exposure times to check for concentration dependence and radiation damage. No concentration dependence was observed. Data were merged using PRIMUS (Konarev et al. 2003), maximizing signal to noise but excluding radiation-affected data points. The radius of gyration was determined to better than an angstrom of precision by using the Guinier approximation. GNOM (Svergun 1992) was used to determine the $\mathrm{P}(\mathrm{r})$ function and assign a Dmax. The output of GNOM was used as input into GASBOR (Svergun et al. 2001) for shape calculations (Fig. 5A). Ten runs of GASBOR were averaged together using the program DAMMAVER. The suite of programs is collectively assembled in the ATSAS suite (Konarev et al. 2006) available at http://www.embl-hamburg.de/biosaxs/ software.html.

Missing amino acids were modeled onto the crystal structure using the program Modeller (Sali and Blundell 1993). Both Rb ${ }^{\mathrm{PL}-\mathrm{P}}$ and $\mathrm{Rb}^{\mathrm{N}-\mathrm{P}}$ structures were used as inputs into Modeller. The following $\mathrm{Rb}$ amino acids were modeled: three residues remaining from a cleaved N-terminal protease site to $54,84-94,172-185$, 353-376 (RbIDL), 500-509, and 772-787. The resulting structure is shown in Supplemental Figure 4A overlaid on the solved $\mathrm{Rb}^{\mathrm{N}-\mathrm{P}}$ structure. The scattering curves calculated from atomic resolution coordinates were generated by FoXS (Schneidman-Duhovny et al. 2010). The programs BilboMD and MES (Pelikan et al. 2009) were used to generate a large ensemble of conformations and define a minimal ensemble of conformations with best fit to the data (Fig. 5A; Supplemental Fig. 4). The structure from Modeller was used as a starting conformation for BilboMD. In the simulation, $\mathrm{RbN}$ and the pocket were treated as rigid domains. $\mathrm{RbIDL}$ was unrestrained such that the relative distance and orientation of the two structured domains could vary while remaining tethered. The loops and termini were also unrestrained, except their $\mathrm{N}$-terminal and $\mathrm{C}$-terminal positions were fixed within their respective rigid domains. In total, 7200 conformations from 36 trajectories run in BilboMD were used in the analysis

\section{Acknowledgments}

This work is supported by grants from the National Institutes of Health (R01CA132685) to S.M.R. and the Department of Energy (DOE) Integrated Diffraction Analysis (IDAT) grant contract number DE-AC02-05CH11231 for SAXS data collection at the Advanced Light Source. J.R.B. is an ARCS Foundation Scholar. G.H. is supported by NIH/NCI P01CA92584 Structural Cell Biology of DNA Repair Machines. S.M.R. is a Pew Scholar in the Biomedical Sciences, supported by The Pew Charitable Trusts.

\section{References}

Adams PD, Afonine PV, Bunkoczi G, Chen VB, Davis IW, Echols N, Headd JJ, Hung LW, Kapral GJ, Grosse-Kunstleve RW, et al. 2010. PHENIX: A comprehensive Python-based system for macromolecular structure solution. Acta Crystallogr D Biol Crystallogr 66: 213-221.

Balog ER, Burke JR, Hura GL, Rubin SM. 2011. Crystal structure of the unliganded retinoblastoma protein pocket domain. Proteins 79: 2010-2014.

Binne UK, Classon MK, Dick FA, Wei W, Rape M, Kaelin WG Jr, Naar AM, Dyson NJ. 2007. Retinoblastoma protein and anaphase-promoting complex physically interact and functionally cooperate during cell-cycle exit. Nat Cell Biol 9: 225-232.

Brehm A, Miska EA, McCance DJ, Reid JL, Bannister AJ, Kouzarides T. 1998. Retinoblastoma protein recruits histone deacetylase to repress transcription. Nature 391: 597-601.

Brown VD, Phillips RA, Gallie BL. 1999. Cumulative effect of phosphorylation of $\mathrm{pRB}$ on regulation of E2F activity. Mol Cell Biol 19: 3246-3256.

Buchkovich K, Duffy LA, Harlow E. 1989. The retinoblastoma protein is phosphorylated during specific phases of the cell cycle. Cell 58: 1097-1105.

Burke JR, Deshong AJ, Pelton JG, Rubin SM. Phosphorylationinduced conformational changes in the retinoblastoma protein inhibit E2F transactivation domain binding. 2010. J Biol Chem 285: 16286-16293. 
Burkhart DL, Sage J. 2008. Cellular mechanisms of tumour suppression by the retinoblastoma gene. Nat Rev Cancer 8: 671-682.

DeCaprio JA, Ludlow JW, Lynch D, Furukawa Y, Griffin J, Piwnica-Worms H, Huang CM, Livingston DM. 1989. The product of the retinoblastoma susceptibility gene has properties of a cell cycle regulatory element. Cell 58: 10851095.

Emsley P, Cowtan K. 2004. Coot: Model-building tools for molecular graphics. Acta Crystallogr D Biol Crystallogr 60: 2126-2132.

Gorges LL, Lents NH, Baldassare JJ. 2008. The extreme COOH terminus of the retinoblastoma tumor suppressor protein $\mathrm{pRb}$ is required for phosphorylation on Thr-373 and activation of E2F. Am J Physiol Cell Physiol 295: C1151-C1160. doi: 10.1128/MCB.21.14.4773-4784.2001.

Hao B, Zheng N, Schulman BA, Wu G, Miller JJ, Pagano M, Pavletich NP. 2005. Structural basis of the Cks1-dependent recognition of $\mathrm{p} 27(\mathrm{Kip} 1)$ by the $\mathrm{SCF}(\mathrm{Skp} 2)$ ubiquitin ligase. Mol Cell 20: 9-19.

Harbour JW, Luo RX, Dei Santi A, Postigo AA, Dean DC. 1999. Cdk phosphorylation triggers sequential intramolecular interactions that progressively block $\mathrm{Rb}$ functions as cells move through G1. Cell 98: 859-869.

Hassler M, Singh S, Yue WW, Luczynski M, Lakbir R, SanchezSanchez F, Bader T, Pearl LH, Mittnacht S. 2007. Crystal structure of the retinoblastoma protein $\mathrm{N}$ domain provides insight into tumor suppression, ligand interaction, and holoprotein architecture. Mol Cell 28: 371-385.

Hayward S, Berendsen HJ. 1998. Systematic analysis of domain motions in proteins from conformational change: New results on citrate synthase and T4 lysozyme. Proteins 30: 144-154.

Hinds PW, Mittnacht S, Dulic V, Arnold A, Reed SI, Weinberg RA. 1992. Regulation of retinoblastoma protein functions by ectopic expression of human cyclins. Cell 70: 993-1006.

Holt LJ, Tuch BB, Villen J, Johnson AD, Gygi SP, Morgan DO. 2009. Global analysis of Cdk1 substrate phosphorylation sites provides insights into evolution. Science 325: 1682-1686.

Howell PL, Smith GD. 1992. Identification of heavy-atom derivatives by normal probability methods. J Appl Crystallogr 25: $81-86$.

Hura GL, Menon AL, Hammel M, Rambo RP, Poole FL II, Tsutakawa SE, Jenney FE Jr, Classen S, Frankel KA, Hopkins RC, et al. 2009. Robust, high-throughput solution structural analyses by small angle X-ray scattering (SAXS). Nat Methods 6: 606-612.

Ji P, Jiang H, Rekhtman K, Bloom J, Ichetovkin M, Pagano M, Zhu L. 2004. An Rb-Skp2-p27 pathway mediates acute cell cycle inhibition by $\mathrm{Rb}$ and is retained in a partial-penetrance Rb mutant. Mol Cell 16: 47-58.

Kim SY, Ferrell JE Jr. 2007. Substrate competition as a source of ultrasensitivity in the inactivation of Wee1. Cell 128: 11331145.

Knudsen ES, Wang JY. 1996. Differential regulation of retinoblastoma protein function by specific Cdk phosphorylation sites. J Biol Chem 271: 8313-8320.

Knudsen ES, Wang JY. 1997. Dual mechanisms for the inhibition of E2F binding to RB by cyclin-dependent kinase-mediated RB phosphorylation. Mol Cell Biol 17: 5771-5783.

Koivomagi M, Valk E, Venta R, Iofik A, Lepiku M, Balog ER, Rubin SM, Morgan DO, Loog M. 2011. Cascades of multisite phosphorylation control Sicl destruction at the onset of $\mathrm{S}$ phase. Nature 480: 128-131.

Konarev PV, Volkov VV, Sokolova AV, Koch MHJ, Svergun DI. 2003. PRIMUS: A Windows PC-based system for small-angle scattering data analysis. I Appl Crystallogr 36: 1277-1282.
Konarev PV, Petoukhov MV, Volkov VV, Svergun DI. 2006. ATSAS 2.1, a program package for small-angle scattering data analysis. J Appl Crystallogr 39: 277-286.

Lee JO, Russo AA, Pavletich NP. 1998. Structure of the retinoblastoma tumour-suppressor pocket domain bound to a peptide from HPV E7. Nature 391: 859-865.

Lee C, Chang JH, Lee HS, Cho Y. 2002. Structural basis for the recognition of the E2F transactivation domain by the retinoblastoma tumor suppressor. Genes Dev 16: 3199-3212.

Lees JA, Buchkovich KJ, Marshak DR, Anderson CW, Harlow E. 1991. The retinoblastoma protein is phosphorylated on multiple sites by human cdc2. EMBO J 10: 4279-4290.

Lents NH, Gorges LL, Baldassare JJ. 2006. Reverse mutational analysis reveals threonine-373 as a potentially sufficient phosphorylation site for inactivation of the retinoblastoma tumor suppressor protein (pRB). Cell Cycle 5: 1699-1707.

Leslie AG. 2006. The integration of macromolecular diffraction data. Acta Crystallogr D Biol Crystallogr 62: 48-57.

Liu X, Marmorstein R. 2007. Structure of the retinoblastoma protein bound to adenovirus E1A reveals the molecular basis for viral oncoprotein inactivation of a tumor suppressor. Genes Dev 21: 2711-2716.

Manning AL, Dyson NJ. 2011. pRB, a tumor suppressor with a stabilizing presence. Trends Cell Biol 21: 433-441.

Mccoy AJ, Grosse-Kunstleve RW, Adams PD, Winn MD, Storoni LC, Read RJ. 2007. Phaser crystallographic software. I Appl Crystallogr 40: 658-674.

Mimura S, Seki T, Tanaka S, Diffley JF. 2004. Phosphorylationdependent binding of mitotic cyclins to Cdc6 contributes to DNA replication control. Nature 431: 1118-1123.

Nash P, Tang X, Orlicky S, Chen Q, Gertler FB, Mendenhall MD, Sicheri F, Pawson T, Tyers M. 2001. Multisite phosphorylation of a CDK inhibitor sets a threshold for the onset of DNA replication. Nature 414: 514-521.

Nielsen SJ, Schneider R, Bauer UM, Bannister AJ, Morrison A, $\mathrm{O}^{\prime}$ Carroll D, Firestein R, Cleary M, Jenuwein T, Herrera RE, et al. 2001. Rb targets histone H3 methylation and HP1 to promoters. Nature 412: 561-565.

Orlicky S, Tang X, Willems A, Tyers M, Sicheri F. 2003. Structural basis for phosphodependent substrate selection and orientation by the SCFCdc4 ubiquitin ligase. Cell 112: 243-256.

Pelikan M, Hura GL, Hammel M. 2009. Structure and flexibility within proteins as identified through small angle X-ray scattering. Gen Physiol Biophys 28: 174-189.

Pettersen EF, Goddard TD, Huang CC, Couch GS, Greenblatt DM, Meng EC, Ferrin TE. 2004. UCSF Chimera-a visualization system for exploratory research and analysis. J Comput Chem 25: 1605-1612.

Putnam CD, Hammel M, Hura GL, Tainer JA. 2007. X-ray solution scattering (SAXS) combined with crystallography and computation: Defining accurate macromolecular structures, conformations and assemblies in solution. Q Rev Biophys 40: 191-285.

Rambo RP, Tainer JA. 2011. Characterizing flexible and intrinsically unstructured biological macromolecules by SAS using the Porod-Debye law. Biopolymers 95: 559-571.

Rubin SM, Gall AL, Zheng N, Pavletich NP. 2005. Structure of the $\mathrm{Rb}$ C-terminal domain bound to E2F1-DP1: A mechanism for phosphorylation-induced E2F release. Cell 123: 1093-1106.

Sali A, Blundell TL. 1993. Comparative protein modelling by satisfaction of spatial restraints. J Mol Biol 234: 779-815.

Schneidman-Duhovny D, Hammel M, Sali A. 2010. FoXS: A Web server for rapid computation and fitting of SAXS profiles. Nucleic Acids Res 38: W540-W544. doi: 10.1093/nar/gkq461.

Singh M, Krajewski M, Mikolajka A, Holak TA. 2005. Molecular determinants for the complex formation between the reti- 
Burke et al.

noblastoma protein and LXCXE sequences. J Biol Chem 280: 37868-37876.

Svergun DI. 1992. Determination of the regularization parameter in indirect-transform methods using perceptual criteria. J Appl Crystallogr 25: 495-503.

Svergun DI, Petoukhov MV, Koch MH. 2001. Determination of domain structure of proteins from X-ray solution scattering. Biophys J 80: 2946-2953.

van den Heuvel S, Dyson NJ. 2008. Conserved functions of the pRB and E2F families. Nat Rev Mol Cell Biol 9: 713-724.

Weinberg RA. 1995. The retinoblastoma protein and cell cycle control. Cell 81: 323-330.

Xiao B, Spencer J, Clements A, Ali-Khan N, Mittnacht S, Broceno C, Burghammer M, Perrakis A, Marmorstein R, Gamblin SJ. 2003. Crystal structure of the retinoblastoma tumor suppressor protein bound to E2F and the molecular basis of its regulation. Proc Natl Acad Sci 100: 2363-2368.

Zarkowska T, Mittnacht S. 1997. Differential phosphorylation of the retinoblastoma protein by G1/S cyclin-dependent kinases. J Biol Chem 272: 12738-12746. 


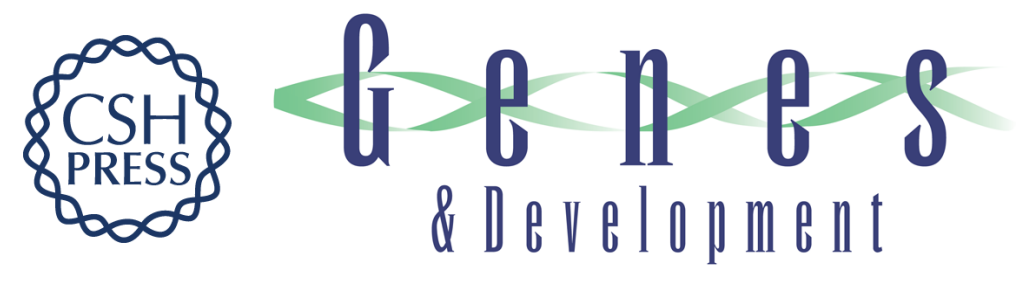

\title{
Structures of inactive retinoblastoma protein reveal multiple mechanisms for cell cycle control
}

\author{
Jason R. Burke, Greg L. Hura and Seth M. Rubin
}

Genes Dev. 2012, 26: originally published online May 8, 2012

Access the most recent version at doi:10.1101/gad.189837.112

\section{Supplemental http://genesdev.cshlp.org/content/suppl/2012/05/03/gad.189837.112.DC1 \\ Material}

Related Content

Phosphorylation puts the pRb tumor suppressor into shape

Andreas M.F. Heilmann and Nicholas J. Dyson

Genes Dev. June , 2012 26: 1128-1130

References This article cites 52 articles, 10 of which can be accessed free at:

http://genesdev.cshlp.org/content/26/11/1156.full.html\#ref-list-1

Articles cited in:

http://genesdev.cshlp.org/content/26/11/1156.full.html\#related-urls

\section{License}

Email Alerting

Service

Receive free email alerts when new articles cite this article - sign up in the box at the top right corner of the article or click here.

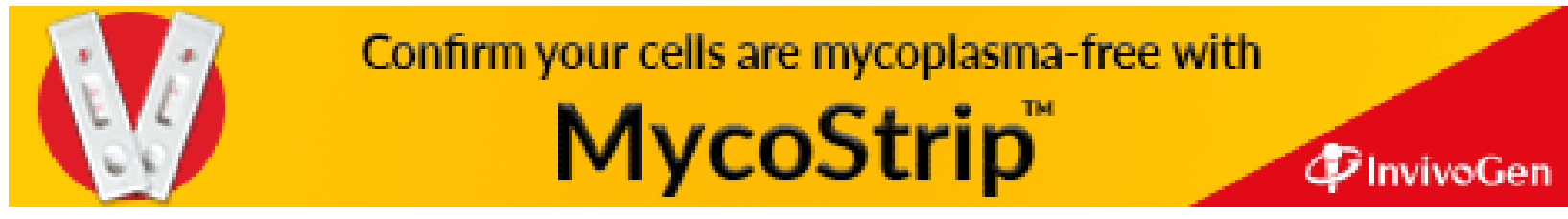

